\title{
KEBIJAKAN PEMERINTAH DAERAH PEMINDAHAN PASAR RAWAJAYA KE PASAR WOSIA (STUDI KASUS DI KECAMATAN TOBELO KABUPATEN HALMAHERA UTARA)
}

\author{
Ibnu Kanaha \\ FISH, Universitas Halmahera Tabelo \\ Email: ibnukanaha@gmail.com
}

\begin{abstract}
The purpose of this research is to know and analyze Local Government Policy in Rawajaya Market Transfer to Wosia Market. The research method is qualitative descriptive. Technique of completion of interview data, observation, and documentation. Data analysis using. The research finds commitment in its development is still very low quality. This finding is still lacking to anticipate obstacles that hamper violence against pendangang, the socialization policy, the policy is not maximal. Not strict in the form of policy, for example there is still sales in the market rawajaya. The government returns or improves the content of the message if it does not sell again in the market rawajaya. Governments can change and can contribute to thinking in policy, the government creates the market of Wosia.
\end{abstract}

Keywords: government policy, transfer market Rawajaya, Wosia

\section{PENDAHULUAN}

Keberadaan Pedagang Kaki Lima (PKL) merupakan suatu fenomena kegiatan perekonomian rakyat kecil di Desa Rawajaya Kecamatan Tobelo Kabupaten Halmahera Utara. Akhir-akhir ini fenomena pemindahan Pasar Rayawaja ke Pasar Wosia terhadap para Pedangang Kaki Lima (PKL) marak terjadi. Para Pedangang Kaki Lima (PKL) dengan Satpol PP dipindahan oleh Aparat Pemerintah Daerah seolah-olah mereka tidak memiliki hak asasi manusia dalam bidang ekonomi, sosial dan budaya. Pedangang Kaki Lima (PKL) hanya untuk memenuhi kebutuhan pokok sehari-hari.

Pedagang Kaki Lima (PKL) ini timbul dari adanya suatu kondisi Pembangunan Perekonomian dan Sosial dan Pendidikan yang tidak merata di seluruh NKRI (Negara Kesatuan Republik Indonesia) ini. Pedangang Kaki Lima (PKL) ini timbul dari akibat tidak tersedianya lapangan pekerjaan bagi rakyat kecil yang tidak memiliki kemampuan dalam berproduksi. Pemerintah sebenarnya memiliki tanggung jawab dalam melaksanakan pembangunan bidang perekomian sosial, pendidikan, dan penyediaan lapangan pekerjaan.
Fenomena Pedagang Kaki Lima di Kabupaten Halmahera Utara khususnya Kecamatan Tobelo, Desa Rawajaya merupakan permasalahan yang pelik dan sukar dicari solusinya sampai sekarang selalu muncul walau telah ditangani pemerintah. Pada dasarnya, Pedangang Kaki Lima (PKL) ini timbul dari adanya ketimpangan sosial dan pembangunan perekonomian serta pelayanan masyarakat yang tidak merata di Kabupaten Halmahera Utara, termasuk Kota Tobelo. Karena Kota Tobelo khususnya Desa Rawa Jaya merupakan sentral ekonomi rakyat dan menjadi suatu hal yang wajar bila masyarakat banyak yang menggantungkan kelangsungan hidupnya di bidang perdagangan di Kabupaten Halamahera Utara ini.

Kondisi ini sungguh merupakan suatu hal yang ironis di tengah-tengah usaha para PKL mencari nafkah demi kelangsungan hidupi keluarganya. Para PKL di Kabupaten Halamahera Utara menjual berbagai jenis dagangang seperti sayur mayur, buah-buahan, ikan serta berbagai macam pengadaan barang dangangang dan lain sebagainya. Akan tetapi tentu kita melihat dari sisi dampak lingkungan 
memberikan implikasi yang positif yaitu tertatanya lingkungan dengan baik, dengan pengolahan sampah maupun limbah pasar, penghijauan sekitar pasar relokasi, sehingga lingkungan pasar menjadi asri dan tidak terlihat kesan kumuh (ramah lingkungan). Sedangkan dampak negatif yaitu menurunnya modal dan pendapatan, meningkatnya biaya operasional, menurunnya aktivitas pasar (produksi, distribusi dan konsumsi), melemahnya jaringan sosial (pelanggan) dan menurunnya kesempatan pedagang untuk ikut dalam kelompok-kelompok sosial non formal. Berdasarkan latar belakan masalah di atas, rumusan masalah yang dapat disusun adalah bagaimana kebijakan pemerintah daerah dalam pemindahan Pasar Rawajaya Ke Pasar Wosia, serta faktor-faktor penghambat dan pendukung tentang pemindahan Pasar Rawajaya Ke Pasar Wosia.

\section{TINJAUAN PUSTAKA}

\section{Konsep Kebijakan Publik}

Setiap organisasi, institusi atau instansi sampai pada tingkat pemerintah pusat dan pemerintah daerah tentu perlu kebijakan. Pada dasarnya dapat berupa, undang-undang peraturan-peraturan, keputusan pejabat negara atau organisasi yang menjadi pedoman, petunjuk kegiatan atau arah dari segala langkah organisasi dan intitusi sampai pada tingkat negara (State). Arti lain, dari kebijakan publik adalah keputusan pemerintah yang bersifat umum dan berlaku untuk seluruh anggota masyarakat atau keputusan yang bersifat kasuistis untuk sesuatu hal pada suatu waktu tertentu (Sudarsono, 1992:47). Ini sejalan dengan pengertian publik itu sendiri dalam bahasa Indonesia yang berarti pemerintah, masyarakat atau umum.

Kebijakan dapat diartikan sebagai jalan yang panjang dan harus ditempuh suatu organisasi, instansi dan negara apapun bentuknya dengan demikian dapat dikatakan bahwa kebijakan publik dimaksudkan dapat berupa undang-undang, peraturan-peraturan, atau ketentuan hukum yang menjadi pedoman yang di akui dan mengikat mengenai cara-cara bertindak dan batas-batas tindakan, diterima dengan sadar yang menuntun masalah yang berkaitan suatu pilihan.
Untuk menjelaskan apa yang dimaksud dengan kebijakan menurut Terry \& Franlin, 1982 (Lexie A Lumengkewas, 2006:20) kebijakan adalah suatu ucapan atau tulisan yang memberikan petunjuk umum tentang penetapan ruang lingkup yang memberi batas-batas dan arah kepada para manajemen pimpinan) untuk bergerak. Berdasarkan pendapat tersebut setiap pemerintah melakukan atau mengeluarkan kebijakan tentu menganalisis sebuah strategi pencapaianya agar pemerintah tidak kehilangan arah, karena sebuah kebijakan yang baik akan menghindari jebakan dengan jalan merumuskan secara eksplisit Davis (Suharto, 2007:5) 1). Pernyataan resmi mengenai pilihan-pilihan yang akan dilakukan, 2). Model sebab dan akibat yang mendasari kebijakan, 3). Hasil-hasil yang akan dicapai dalam kurung waktu tertentu.

Dengan proses tahapan-tahapan tentu kebijakan efektif memperhatikan keselarasan antara usulan kebijakan dengan agenda dan strategi besar (grand design) pemerintah. Pernyatan di atas bahwa sebelum merumuskan kebijakan publik tentu dilibatkan semua kepentingan kebijakan dan pengguna kebijakan sehingga kebijakan tersebut pada sasarannya. Kebijakan adalah kebijakan pemerintah yang berkaitan dengan tindakan yang memiliki dampak yang langsung terhadap kesejahteraan warga negara melalui penyediaan pelayanan sosial atau bantuan keuangan (Solichin Abdul Wahab, 2004:21). Menurut pendapat tersebut, kebijakan pada dasarnya suatu tindakan yang mengarah kepada tindakan yang memiliki dampak yang langsung terhadap kesejahteraan warga negara; Pertama, kebijakan negara, pemerintah lebih merupakan tindakan yang mengarah pada tujuan daripada sebagai prilaku atau tindakan yang serba acak dan kebetulan, artinya kebijakan bukan tiba saat tiba akal tanpa menganalisa konsekuensi-konsekuensi terjadi pada pengguna kebijakan. Kedua, kebijakasanaan pada hakekatnya terdiri atas tindakan-tindakan yang saling berkaitan dan berpola yang mengarah pada tujuan tertentu yang dilakukan oleh pejabat-pejabat pemerintah dan bukan merupakan keputusan-keputusan yang berdiri sendiri-sendiri, misalnya kebijaksanaan tindakan hanya mencakup keputusan untuk membuat undang-undang yang 
berhubungan dengan implementasi pemaksaan pemberlakuannya. Ketiga, kebijaksanaan berhubungan dengan apa yang senyatannya dilakukan pemerintah dalam bidang-bidang tertentu, misalnya dalam mengatur ekonomi sosial, program masyarakat berpenghasilan rendah dan bukan hanya sekedar apa yang ingin pemerintah dilakukan dalam bidang-bidang tertentu.

Dari sejumlah pernyataan para ahli di atas penulis mengkolaborasikan dengan persoalan selama ini kebijakan tentang pemindahan Pasar Rawajaya ke Pasar Wosia, Pemerintah Kabupaten Halmahera Utara belum mendapatkan solusi sejaumana kebijakan sehingga masyarakat tidak tertekan selalau dalam melakukan aktifitas berjualan. Sehubungan dengan itu perlu dianalisis dan diketahui faktor-faktor apa yang membentuk kebijakan atau akibat-akibat yang ditimbulkan oleh kebijakan tersebut.

\section{Implementasi Kebijakan}

Implementasi kebijakan bukan hanya direkomendasikan untuk dipilih oleh pengambilan kebijakan dan bukan sebuah jaminan bahwa kebijakan tersebut pasti berhasil dalam implementasinya. oleh karena itu, implementasi sebagai proses untuk mewujudkan tujuan kebijakan sering disebut sebagai tahapan yang penting (crical stage). Penting karena tahapan ini merupakan "jembatan" antara dunia konsep dengan dunia realita seperti dikemukan Grindle (Purwanto dan Susistyastuti, 2012:69) yang menyebutkan bahwa implementasi "estabilish a link that allows goal of pulic policies to be realized as outcome of governmental activity". Dunia konsep dan yang dimaksud di sini tercermin dalam kondisi ideal, sesuatu yang dicita-citakan untuk diwujudkan sebagaimana terformulasikan dalam kondisi kebijakan, sementara dunia nyata adalah realitas di mana masyarakat sebagai kelompok sasaran kebijakan sedang bergelut dengan berbagai persoalan sosial, ekonomi dan politik.

$$
\text { Implementasi kebijakan menjadi }
$$

"jembatan" karena ketika sebelum dilakukan proses implementasi kebijakan tentu disampaikan kepada kelompok sasaran sebagai upaya nyata untuk mencapai tujuan kebijakan.
Untuk menjamin implementasi dapat berjalan dengan lancar, sebelum kegiatan penyampaian berbagai keluaran kebijakan dilakukan kepada kelompok kelompok sasaran dimulai perlu didahulukan dengan penyampaian informasi kepada kelompok sasaran, tujuan pemberian informasi agar kelompok sasaran memahami kebijakan yang akan diimplementasikan sehingga mereka tidak hanya akan dapat menerima berbagai program yang diinisiasi oleh pemerintah akan tetapi berpartisipasi aktif didalam upaya untuk mewujudkan tujuan-tujuan kebijakan.

Informasi yang disampaikan dalam mencari dukungan terhadap kelompok sasaran ini paling tidak harus mencakup berbagai hal: Pertama, penjelasan secara lengkap tentang tujuan kebijakan, manfaat serta keuntungan yang akan dirasakan oleh kelompok sasaran, stakeholder yang terlibat, dan mekanisme kegiatan sebuah kebijakan atau program. Kedua, kegiatan penyampaian informasi ini biasanya disebut sebagai kegiatan sosial. Sosialisasi dapat dilakukan melalui dua cara sosialisasi cara langsung dilakukan melalui dialog interaktif dengan kelompok sasaran sedangkan sosialisasi tidak langsung tidak berinteraksi dengan kelompok sasaran maupun stakholders secara (face to face bureucrats) melalui papan pengumuman, pamlet, spanduk, brosur, iklan layanan masyarakat lewat TV dan lain-lain.

Merujuk pada pendapat deLeon (Purwanto dan Sulistyastuti, 2012:69) implementasi mempengaruhi keberhasilan implementasi tidak hanya menyangkut dimensi administrasi dan manajemen yang sangat dipengaruhi, akan tetapi gagasan-gagasan pengambilan kebijakan, pandangan ini bahwa kebijakan tersebut untuk berhasil:

a. Masyarakat memilki pemahaman lebih baik tentang tujuan program sekaligus memberikan input,

b. Masyarakat memehami akan keuntungan program, sekaligus dapat melakukan indentifikasi kendalanya

c. Masyarakat mengenali tentang mekanisme implementasi program dengan lebih baik, 
d. Ketika masyarakat mengetahu mekanismenya maka masyarakat bisa terlibat dalam melakukan kontrol.

Kasus relokasi Pedangang Kaki Lima (PKL) di Kota Tobelo Kabupaten Halmahera Utara barangkali bisa dijadikan contoh dengan pandangan peneliti penerapan kebijakan pemindahan Pasar Rawajaya ke Pasar Wosia. Persoalan terbesar dalam proses pemindahan Pedangang Kaki Lima (PKL) sering dihadapi oleh pemerintah adalah terjadinya konflik. Argumen utama yang dimiliki oleh Pedangang Kaki Lima (PKL) adalah apakah keuntungan yang sama akan diperoleh ditempat yang baru dalam hal ini di Pasar Wosia. Akan tetapi tidak demikian dengan Pemerintah Kota Tobelo Kabupaten Halmahera Utara yang berhasil memindahkan Pasar Rawajaya ke Pasar Wosia sehingga gesekan konflik selalu melakukan aktifitas Pedangang Kaki Lima, ini pengalaman yang sangat berharga Bupati baru Frans Maneri dengan mengundang para Pedangang Kaki Lima dicari solusi dengan penolakan dari Pedangang kaki Lima (PKL) dengan itu tentu lebih efektif daripada harus mengeluarkan tameng dan tongkat petungan Satpol PP. Persoalan dikemukan di atas adalah permasalahan yang memuncul dalam proses implementasi kebijakan perlu ditinjau kembali khususnya daerah masih tahapan berkembang.

\section{Teori Pemerintah Dan Asas Desentralisasi}

Perkembangan hukum dan politik menuntut penyelenggaraan pemerintahan daerah yang lebih efektif dan akuntabel tentu pemerintah perlu dilakukan kebijakan sesuai dengan aspirasi masyarakat secara terbuka dengan melibatkan partisipasi masyarakat. Oleh karena itu penyelenggaraan Pemerintahan Daerah Kabupaten Halmahera Utara dibentuk untuk menghindari keadaan dimana sebuah wilaya mengalami kekacauan.

Sebagaimana dalam UU No. 23 tahun 2014 tentang Pemerintahan Daerah, desentralisasi adalah penyerahan wewenang pemerintahan oleh pemerintah kepada daerah otonom untuk mengatur dan mengurus urusan pemerintahan dalam Sistem Negara Kesatuan Republik Indonesia. Pelimpahan wewenang kepada pemerintahan daerah semata-mata untuk mencapai suatu pemerintahan yang efisien.

Tujuan desentralisasi adalah 1). Mencegah pemusatan keuangan, 2). Sebagai usaha pendemokrasian pemerintahan daerah untuk mengikutsertakan rakyat bertanggungjawab terhadap penyelenggaraan pemerintahan, 3). Penyusunan program-program untuk perbaikan sosial ekonomi pada tingkat lokal sehingga dapat lebih realistis.

\section{Konsep Ekonomi Pasar}

Pasar memiliki posisi khusus di dalam Pemerintahan Indonesia. Karena keberadaan pasar menjadi pusat ekonomi masyarakat, dan ketergantungan Pedangang Kaki Lima atau pedangang kecil dengan keberadaan pasar membuat pemerintah sebagai regulasi perlu melindungi dan memberdayakannya. Kebijakankebijakan telah dibuat, antara lain dalam Peraturan Menteri dalam Negara Kesaruan Republik indonesia (PERMENDAGRI) Nomor 20 Tahun 2012 tentang Pengeloaan dan Pemberdayaan Pasar. Peraturan tersebut mengatur tentang berbagai aspek agar pasar tetap dapat dimanfaatkan konsumen sebagai pusat perbelanjaan guna memenuhi kebutuhan publik. Tujuan untuk mewujudkan pasar yang tertib, teratur, aman, bersih dan sehat, sebagai pelayanan publik, sebagai pengerak, roda perekonomian daerah dan berdaya saing. Dengan ada PERMEN Nomor 20 Tahun 2012 tentu pemerintah menjadi tanggungjawab pemerintah untuk mengelola dan memberdayakan agar pasar mampu berkembang dan tetap menjadi pusat ekonomi masyarakat. Selain Permendagri Nomor 20 tahun 2012 sebelumnya ada Peraturan Presiden Nomor 112 tahun 2007 dan Peraturan Menteri Perdangang Republik Indonesia Nomor 53 tahun 2008 yang mengatur tetang penataan dan pembinaan Pasar Pusat Perbelanjaan. Peraturan-peraturan tersebut dibuat untuk membantu pasar dapat bertahan dan bersaing dengan perkembangan perekonomian khususnya dalam perdangan Kabupaten Halmahera Utara. 


\section{METODE PENELITIAN}

Jenis penelitian menggunakan penelitian kualitatif dengan pendekatan deduktif dan induktif. Sumber data penelitian ini adalah data primer, yaitu data yang diamati secara langsung dan diperoleh melalui wawancara berkaitan dengan objek penelitian. Teknik analisa data menurut Miles dan Huberman 1992, (Sugiono, 2012) yang terdiri dari tiga tahapan yaitu: 1). Reduksi data (data reduction), data yang didapatkan dilapangan kemudian diuraikan dan dibuat dalam bentuk laporan, laporan tersebut direduksi atau dipilih untuk dikaji berdasarkan rumusan masalah penelitian, 2). Penyajian Data yaitu menggambarkan secara keseluruahan data penelitian yang didapatkan dilapangan dengan menyesuaikan informan yang diperoleh dari informasi, 3). Verifikasi data atau penarikan penarikan kesimpulan yang dilakukan diakhiri penelitian, dimana data yang diperoleh dilapangan kemudian direduksi dan dianalisa dengan menghubungkan masalah yang diteliti kemudian ditarik kesimpulan akhir.

\section{HASIL DAN PEMBAHASAN}

\section{Kebijakan Bupati}

Kebijakan pada dasarnya suatu tindakan yang mengarah kepada tujuan tertentu dan bukan hanya sekedar keputusan untuk melakukan sesuatu. Kebijakan seyogyanya diarahkan pada apa yang senyatanya dilakukan oleh pemerintah dan bukan sekedar apa yang ingin dilakukan oleh pemerintah. Hal ini merupakan suatu proses kebijakan pemerintah melalui berbagai pertimbangan-pertimbangan demi berjalannya program pemerintah yang telah ditetapkan.

Berdasarkan hasil wawancara tentang kebijakan bupati tersebut dapat dilihat pada beberapa informan sebagai berikut: Ketika peneliti bertanya kepada Camat Tabelo tentang kebijakan bupati mengenai pemindahan Pasar Rawajaya ke Pasar Wosia, beliau menjawab:

"Sangat setuju, karena dalam kerangka untuk mengembangkan kota Tobelo untuk kedepannya dimana orang tahu bersama bahwa kawasan Tobelo di sepanjang jalan kemakmuran menjadi aikon pusat ekonomi, Kabupaten Halmahera Utara untuk mengembangkan ke depan pemerintah daerah harus melihat bahwa pasar tradisional itu penempatan harus di sebelah utara dan selatan, oleh karena berkenaan dengan pasar yang sudah dibangun oleh Provinsi dan Kabupaten Maluku Utara pada tahun 1996 di pasar yang ada di Wosia supaya agar tidak mubazir. Pasar Wosia harus dimanfaatkan harus kembali lagi pemerintah dalam mengembangkan kota ke depan berdasarkan RT/RW yang kemudian turunnya RTDL (Rencana Detail Tata Ruang), maka pemerintah memindahkan pasar yang ada di pusat kota Rawajaya ke pasar Wosia yang sekarang."

Selanjutnya peneliti melanjutkan pertanyaan kembali kepada informan, faktorfaktor apa dan pendukung tetang kebijakan bupati tentang pemindahan pasar Rawajaya ke pasar Wosia.

"1. Pedangan kaki lima tidak memiliki kesadaran, 2. Pemerintah tidak konsiten dalam hal melakukan penertiban pemimdahan pasar. 3. Pengembangan kota lebih nampak dilakukan pemindahan pasar sebagai rencana detail tata ruang agar kota jangan lagi terlihat kumuh, untuk meningkatkan pasar lebih baik lagi., dengan solusi Dinas terkait harus melakukan penertiban."

Selanjutnya peneliti bertanya hal yang sama kepada informan Kepala Desa Rawajaya tentang kebijakan bupati tersebut.

"Terkait dengan pasar ini menyangkut dengan kebutuhan hidup masyarakat yang ada di Rawajaya, kemudian pasar yang ada di Wosia itu bagus juga, masalahnya yang menjadi alasan atau kendala bagi masyarakat yang ada di Rawajaya waktu pemindahan pasar ke Wosia. Pemerintah telah membuat seperangkat peraturan daerah yang memberikan perlindungan terhadap pasar yaitu peraturan bupati 
tentang pengelolaan pasar. Dengan penerapan kebijakan tersebut memungkinkan pasar dapat semakin berkembang dan menjadi tujuan utama dalam memenuhi kebutuhan sehari-hari. Pengelolaan dan pemberdayaan pasar merupakan hal teknis yang harus dilaksanakan oleh pemerintah. Saya selaku kepala desa tidak terlalu berbuat apa-apa hanyalah mengikuti apa yang pemerintah lakukan tentu punya peran sebagai pemerintah, dan sebagai bawahan harus mengikuti peraturan yang suda di tetapkan, tapi kita juga harus melihat bagaimana dengan kebutuhan masyarakat. Artinya semua pedagang ikan itu modalnya tidak besar ada yang sehari-hari itu berjual satu ember-dua ember lalu kemudian kalu mereka ke wosia juga itu jau dan itu bisa di kondisikan."

Kemudian peneliti bertanya kepada seorang pedangan kaki lima Bapak Sutono, bagaimana kebijakan pemerintah tentang pemindahan pasar Rawajaya ke pasar Wosia,

"Kebijakan tersebut di nilai baik karena pemerintah mengatur hal yang baik bukan hal yang buruk bagi masyarakat. Namun, di pasar Wosia jangkauan pembelinya masih kurang tetapi pada pasar Rawajaya jangkauan pembelinya sangat ramai, jadi kebanyakan pedangan di pasar Wosia kembali berdangan di pasar Rawajaya."

Pertanyaan yang sama peneliti sampaikan kepada informan Ibu Mei, asal Desa WKO, ia mengatakan bahwa:

"Kalau menurut saya tentang bupati peke kebijakan kase pinda pasar dari Rawajaya ke Wosia itu so bagus, tapi masalahnya banyak pembeli dari bagian utara rasa so talalu jao, sampe dorang jarang-jarang pigi pasar Wosia karena masih ada sebagian penjualan yang masih belum ba pindah di pasar Wosia, usahakan kase pinda semua penjualan jangan, jangan lagi laeng di Rawajaya yang laen di Pasar Wosia, ini kan tara adil, dong pe jualan banyak yang beli sedangkan torang cuma sadiki."

Selanjutnya peneliti memberikan pertanyaan kepada informan yang lain Niko, asal desa Pitu penjual di Pasar Wosia tentang bagaimana kebijakan bupati tersebut, beliau mengatakan bahwa:

"Menrut saya kebijakan ini sudah bagus, karena penjualan ikan dan sayur-mayur dipindakahkan ke pasar Wosia, wajah kota terlihat bersi dan rapi. Selain itu, tong yang dari pitu lebe dekat kalau mobajual, dan tiket oto juga lebih murah, tapi tongmusi lihat lagi dengan kebijakan ini ada dampak yang akan ditimbulkan bagi para penjualan, misalnya kalau dulu tong masisi berjualan di pasar Rawajaya, tong pejualan cepat laku kalau dipasar Wosia laku tapi lama baru abis, karena masih ada yang berjualan dipasar Rawajaya, menurut saya kebijakan ini belum sepenuhnya berhasil."

Dari keterangan informan di atas peneliti dapat menyimpulkan bahwa pemerintah Kabupaten Halamahera Utara dalam hal ini Satpolpp dan aparat kepolisian melalukan tindakan kepada pedangang kaki lima agar tidak lagi mereka berjualan di pasar Rawajaya untuk pemanfaatan atau memfungsikan kembali pasar Wosia, penataan ruang, serta menghilangkan rasa kecemburuan sosial pedagang diantara kedua pasar.

\section{Faktor-Faktor Pendukung dan Penghambat Pedangang Kaki lima (PKL)}

Sebagaimana faktor-faktor yang ditimbulkan kepada Pedangang Kaki lima dalam implementasi kebijakan, adalah kelemahan atau penyebab dalam pelaksanaan kebijakan pemindahan Pasar Rawajaya ke Wosia, menurut informan Ibu Mei.

"Faktor pendukung; adanya masyarakat yang setuju dengan rasa senang adanya pemindahan pasar dari rawajaya ke pasar wosia contohnya masyarakat dari bagian selatan mereka senag karna jaraknya 
mereka bisa jangkau untuk berbelanja. Sedangkan faktor penghambat; banyak pembeli khususnya bagian kota dorang lebe pilih berbelanja di pasar rawajaya karena jaraknya lebih dekat dibandingkan di pasar wosia karena kalau pergi kepasar wosia musti naik oto atau bentor dengan tarif perorangang 500, dan harus antri kita tidak boleh bacepat dan tidak bisa masuk ke dalam pasar."

Kemudian peneliti melanjutkan wawancara dengan pertanyaan yang sama kepada Ibu Hana asal Kao Barat, ia mengatakan bahwa;

"Faktor pendukung; kami setuju dengan kebijakan bupati adanya pemindahan pasar dari Rawajaya ke pasar Wosia tempat nyaman untuk berjualan contohnya sudah disiapkan tempat penjualan, tidak kitoran bapanas dan lingkungan sekitar pengjualan bersi, khususnya masyarakat dari bagian selatan mereka senang karena jaraknya mereka bisa jangkau untuk berbelanja. Sedangkan faktor penghambat; pembelinya kurang kadangkadang satu hari hanya dapat 200.000, itu sopaling banyak dibandingkan pasar Rawajaya banyak itu salah satu faktor penghambat."

Dari beberapa pendapat di atas maka dapat penulis katakan bahwa ternyata masyarakat setuju dengan adanya pemindahan pasar Rawajaya ke pasar Wosia, akan tetapi diharapkan pemerintah lebih tegas untuk pedangang kaki lima yang masih berjualan di pasar Rawajaya.

Peneliti melanjutkan wawancara dengan kepada Bapak Agus sebagai penjualan asal TPI, ia mengatakan bahwa;

"Kalau menurut saya selaku penjualan yang sudah lama, salah satu faktor pendukung adalah sarana yang tersedia contoh tempat jualan dong sokase siap, meja jualan dan lain-lain. Sedangkan faktor penghambat sangat menghambat kehidupan ekonomi keluarga dibandingkan di pasar Wosia penjualan kurang laku, contoh biasanya saya masih di pasar Rawajaya ikan saya sebanyak 50 ekor saya bajual jam 06.00 -jam 12.40 itu suda habis, di pasar Wosia 10 ekor juga sampai jam, 12 belum takore. Ini artinya mempengaruhi manajemen kehidupan keluarga yang sebelumnya suda ditetapkan."

Selanjutnya peneliti juga menanyakan hal yang sama kepada informan Sutono sebagai pedangan kaki lima dipasar Rarawajaya.

"Pertama tempat belum strategis, pembeli yang ada di pasar Wosia masih kurang atau sepi penjualannya, terlalu jauh dari pusat kota, pemerintah tidak memahami masyarakat miskin hanya mengutamakan pengusaha saja, faktor pendukung pasar menjadi lebih rapi atau lebih teratur, lebih laku dibandingkan perjualan di pasar Wosia, pembeli lebih memilih di pasar Rawajaya dengan alasan dekat dan bisa terjangkau kondisi pembeli contoh kami bawa uang 20.000 kami bisa beli Ikan Mala Lugis kalau dipasar Wosia uang kami tidak cukup, harga bentor saja sampai Rp. 20,000 PP.”

Peneliti juga menanyakan hal tersebut kepada informan Kepala Desa Rawajaya, tentang faktor penghambat dan faktor pendukung pemindahan pasar Rawajaya ke pasar Wosia.

"Yang menjadi salah satu faktor penghambat yang menjadi alasannya itu karena jauh, bukan hanya pedagang yang mengeluh tapi pembeli juga mengeluh dengan pemindahan pasar atau dengan kondisi yang ada di Wosia/terminal baru. Hambatannya itu terkait dengan jangkauan pada prinsipnya masyarakat yang ada di Rawajaya mereka suda mengikuti arahan bupati terkait dengan pemindahan pasar, sebelum itu masyarakat dan kepala desa sudah pertemuan/rapat di kantor desa mengenai pemindahan pasar dan pak 
camat juga sempat hadir di pertemuan/rapat waktu itu masyarakat Rawajaya juga sudah berkomitmen untuk bagaimana bersama-sama sehinga bisa menciptakan pasar yang ada di Wosia/terminal baru dan kemudian dengan harapan nantinya yang besar semua masyarakat yang ada di Rawajaya yang berdagang semua harus dan sudah berada di lokasi pasar Wosia/terminal baru. Tapi masalahnya yang menjadi kendala pada masyarakat Rawajaya karena orang luar berjualan di desa Rawajaya sedangkan orang Rawajaya berjualan di Wosia dan itulah yang menjadi kendala di Desa Rawajaya."

Sedangkan faktor pendukung menurut kepala desa tersebut adalah:

"1. Pemerintah daerah membuat perda tentang melarang terkait dengan penjualan di pinggiran jalan. 2. Pemerintah desa juga harus membuat perdes hal yang sama dengan pemerintah daerah. 3. Peraturan daerah semua penjualan harus berjualan di pasar Wosia yang menekan mereka semua untuk kepasar Wosia/terminal baru jadi masyarakat juga merasa tidak ada diskriminasi maksudnya kalau ada satu dua orang berjualan kecil-kecil seperti rica, tomat, satu dua tempat itu harus di arahkan untuk semua harus ke pasar Wosia kemudian dimana-mana orang juga berjualan termasuk di desa Gosoma, Gamsungi, ya otomaatis masyarakat yang ada di Rawajaya tetap mereka bersikeras harus berjualan olehnya itu ditegaskan jangan karena yang di larangkan hanya di pingiran jalan/muka jalan muka toko juga harus dilarang."

Dari beberapa pendapat di atas maka dapat peneliti asumsikan bahwa ternyata faktor penghambat dan pendukung adalah masyarakat lebih cenderung untuk berbelanja dipasar Rawajaya dengan alasan lebih terjangkau dengan keadaan masyarakat, pembeli yang sepi di pasar Wosia, dan jarak pasar tersebut yang jauh dibandingkan dengan pasar Rawajaya.

Dari hasil observasi, peneliti mengamati semua pedangang kaki lima berjualan selalu waswas, karena belum ada keteraturan mereka berjualan, seperti sayur, ikan dan lain-lain masih belum teratur, dengan inisiatif sendiri tidak mengikuti apa yang sudah ditetapkan oleh pemerintah daerah. Terkait dengan hal tersebut, peneliti melakukan wawancara Ibu Ona penjualan asal Desa Gorua, tentang bagaimana cara mengatasi pedangang kaki lima yang masih berjualan masih tetap di desa Rawajaya.

"Menurut saya sebagai penjualan pasar Wosia, saya kurang setuju dengan adanya pemindahan pasar, karena kalau saya yang tinggal di Desa Gorua kong pigi bajual di Wosia itu terlalu jauh, kaerna musti basambung-sambung oto lagi, baru kalau saya bajual di Wosia, pelama baru abis saya pejualan, beda dengan saya masih bajual di pasar Rawajaya karena masih ada penjualan yang masih berjualan di Rawajaya sehingga kami yang berjualan di Wosia tidak lagu (sunyi), beda dengan di Rawajaya karena dekat di pusat kota, ini kan kurang adil olehnya itu pemerintah harus tegas dengan kebijakan dalam hal ini bupati dengan cara apapun namanya sudah ada kebijakan mau tidak mau harus ditegahkan kebijakan tersebut."

Pertanyaan yang sama pula peneliti sampaikan kepada informan yang lain Ibu Siti penjualan pasar Wosia, beliau mengatakan bahwa :

"Seharusnya pemerintah khususnya bupati kalau memang mokase pinda harus kase pinda semua ada yang bajual masih di Rawajaya ada yang di Wosia ini kan tidak adil dan tidak tegas kalau bikin pasar harus dipikirkan jangan bikin pasar satu disini satu disana, sehingga jadi begini selalu kita dikejar-kejar oleh petugas kepolisian dan Satpol. Ini berarti tidak 
bagus, kebijakan macam apa ini tara teratur dan tidak sasaran."

Dari hasil observasi dan wawancara peneliti dengan informan dari Dinas Perindakop, Satpol PP, Pedangang kaki lima, kepala desa Rawajaya dan pendagang kaki lima 2 tempat Pasar Rawajaya dan Pasar Wosia Kabupaten Halmahera Utara, dapat dibuat 3 poin utama dari kebijakan bupati terhadap pemindahan pasar tersebut.

1. Pemerintah lebih memilih tindakan yang mengarah pada pencapaian tujuan daripada sebagai perubahan perilaku atau tindakan, yang serba acak dan kebetulan, artinya kebijakan bukan tiba saat tiba akal tanpa menganalisa konsekuensi-konsekuensi terjadi pada implementasi kebijakan.

2. Kebijakan pada hakekatnya terdiri atas tindakan-tindakan yang saling berkaitan dan berpola yang mengarah pada tujuan tertentu, yang dilakukan oleh pejabat-pejabat pemerintah dan bukan merupakan keputusankeputusan yang berdiri sendiri-sendiri. Perlu melibatkan semua pihak yang akan terdampak pada kebijakan tersebut, agar sebuah keputusan dapat ditaati bersama.

3. Kebijakan berhubungan dengan apa yang senyatanya dilakukan pemerintah dalam bidang-bidang tertentu, misalnya dalam mengatur ekonomi sosial, program masyarakat berpenghasilan rendah dan bukan hanya sekedar apa yang ingin pemerintah dilakukan dalam bidangbidang tertentu. Peneliti melihat persoalan selama ini tentang kebijakan pemindahan Pasar Rawajaya ke Pasar Wosia, Pemerintah Kabupaten Halmahera Utara belum mendapatkan solusi kebaikan bersama, sehingga masyarakat tidak tertekan selalu dalam melakukan aktifitas berjualan.

\section{KESIMPULAN}

Berdasarkan hasil penelitian dapat disimpulkan beberapa hal mengenai kebijakan pemerintah daerah tentang pemindahan Pasar Rawajaya ke pada Pasar Wosia Kabupaten Halmahera Utara bahwa:

1. Implementasi kebijakan pemindahan pasar Rawajaya ke pasar Wosia mengalami banyak kendala, sehingga kebijakan ini tidak dilaksanakan dengan baik (bad execution). Pemerintah merumuskan kebijakan hanya sekedar membuat kebijakan atau keputusan, tanpa memperhitungkan dampak dari implementasi kebijakan tersebut.

2. Pemerintah kurang mengantisipasi terhadap kendala-kendala atau faktor-faktor yang menghambat baik itu sarana dan prasarana, ekonomi sosial (pendapatan PKL) kemampuan SDM, kurangnya sosialisasi dan komitmen antara stekholders dan pihak pemerintah. Selain itu kebijakan yang kurang mendukung (bad condition), hal ini sebabkan dari faktor tempat yang kurang strategis untuk pendangang kaki lima, dan pembeli.

3. Kebijakan pemerintah daerah tentang pemindahan pasar Rawajaya ke pasar Wosia belum terlaksana secara optimal dan mendapat dampat yang positif.

\section{REFERENSI}

Basrowi Suwandi, 2008. Memahami Penelitian Kuantitaf. Jakarta: PT. Rineka Cipta Pressido.

Erwan Agus Purwanto dan Dyah Rati Sulistyastuti, 2012, Implementasi Kebijakan. Konsep dan Aplikasinya di Indonesia. Yogyakarta: GAVA MEDIA.

Solihin Abdul Wahab, 2004. Analisis Kebijaksanaan. Dari Formulasi ke Implementasi Kebijaksanaan Negara. Jakarta: BUMI AKSARA.

Sugiyono, 2012. Metode Penelitian Administrasi, dilengkapi dengan Metode R\&D. Bandung: ALFABETA. 
Suharto, 2007. Kebijakan Sosial Sebagai Kebijakan Publik. Bandung: ALFABETA.

Lexie A Lumengkewas, 2006. Kebijakan Publik. Malang: Wineka Media.

Wayne Parsons, 2008. Public Policy, Pengantar Teori dan Praktik Analisis Kebijakan. Jakarta: Kencana.
Undang-Undang 23 Tahun 2014 tentang Pemerintah Daerah.

Kebijakan Pemerintah Daerah Kabupaten Halmahera Utara No.7 Tahun 2012 Tentang Penataan Pasar Tradisional, Pusat Pembelanjaan dan Toko Modern. 